
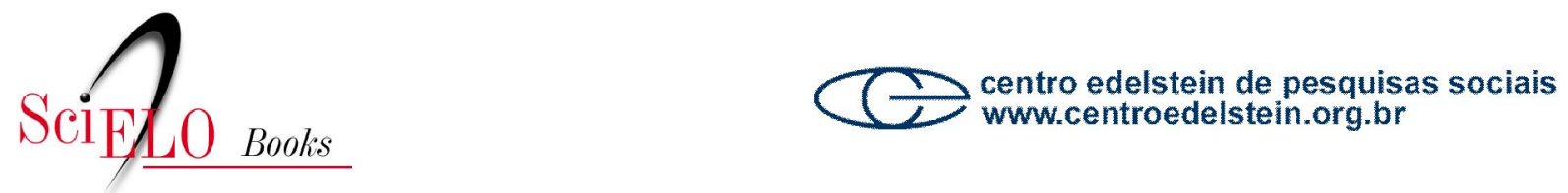

\title{
Nota de esclarecimento
}

\author{
Raimundo Santos
}

SciELO Books / SciELO Livros / SciELO Libros

SANTOS, R. Agraristas políticos brasileiros [online]. Rio de Janeiro: Centro Edelstein de Pesquisas Sociais, 2008. pp. III-IV. Nota de esclarecimento. ISBN: 978-85-99662-81-6. Available from SciELO Books $<$ http://books.scielo.org $>$.

\section{(1) $(1)(2)$}

All the contents of this chapter, except where otherwise noted, is licensed under a Creative Commons Attribution-Non Commercial-ShareAlike 3.0 Unported.

Todo o conteúdo deste capítulo, exceto quando houver ressalva, é publicado sob a licença Creative Commons Atribuição Uso Não Comercial - Partilha nos Mesmos Termos 3.0 Não adaptada.

Todo el contenido de este capítulo, excepto donde se indique lo contrario, está bajo licencia de la licencia Creative Commons Reconocimento-NoComercial-CompartirIgual 3.0 Unported. 


\section{NOTA DE ESCLARECIMENTO}

Os textos que integram a I Parte deste livro provêm da pesquisa "Perfis agraristas brasileiros" ora em andamento no CPDA (Programa de Pós-graduação em Desenvolvimento, Agricultura e Sociedade), da UFRRJ, e cujo objetivo consiste em comparar autores da vertente comunista com a matriz representada por José de Souza Martins, sociólogo que tem na reflexão de Florestan Fernandes sua referência básica.

Enquanto já dediquei vários textos a Caio Prado Jr., até agora só divulguei sobre Alberto Passos Guimarães e Ivan Ribeiro registros pequenos. Há muito tempo, saíram em Estudos Sociedade e Agricultura (junho de 1994) notas de minha autoria a propósito dos 30 anos de Quatro séculos do latifúndio. No final do ano passado, publiquei, naquela mesma revista, um curto artigo chamado "O agrarismo inconcluso de Ivan Ribeiro".

Correndo o risco de expor escritos com repetições e ainda carentes de mais investigação, resolvi compor este volume incluindo as duas partes do relatório da pesquisa acima citada, relativas a Passos Guimarães e a Ivan Ribeiro, assim apresentando um esboço da matriz em que se funda o agrarismo comunista no país. O livro cumpre parcialmente a intenção da pesquisa, mas ainda fica pendente uma publicação sobre as ideias de José de Souza Martins. Este autor, não seria exagero dizer, tem muita influência não só nos movimentos sociais (CPT-MST) do tempo mais recente, mas também em toda uma geração de estudiosos. A nosso ver, atentar para essa dimensão da obra do sociólogo da USP constitui um cometimento instigante na compreensão das mobilizações rurais dos dias de hoje.

Dei a este volume o nome de Agraristas políticos brasileiros, chamando a atenção para um aspecto importante no estudo dos três ensaístas aqui resenhados: são autores que formulam, para o campo de esquerda do seu respectivo tempo, argumentos muito além do registro da presença comunista no mundo rural. Neste sentido, espero deixar seus nomes associados a lineamentos da matriz comunista, com todas as aporias que ela carrega: a interpretação de Brasil (Caio Prado), a habilidade no agir político (Passos Guimarães) e a hipótese prussiana como cânone interpretativo-programático (Ivan Ribeiro). O volume traz uma II Parte com textos dos próprios ensaístas, selecionados entre os mais expressivos da publicística que cada um deles dedicou ao tema agrário e rural. O leitor encontrará no apêndice uma resolução pecebista que está presente em todos os ensaios da I PARTE: a Declaração sobre a política do PCB.

Agradeço os apoios recebidos do Núcleo de Estudos sobre Agricultura e Desenvolvimento (NEAD), da Fundação Astrojildo Pereira, de Brasília, do Instituto Interamericano de Cooperação para a Agricultura (IICA) e do CPDA, sem os quais a edição do presente livro não teria sido possível. 